\title{
Regulation of embryo survival in cattle
}

\author{
W. W. Thatcher ${ }^{1}$, A. Guzeloglu', A. Meikle², S. Kamimura ${ }^{3}$, \\ T. Bilby ${ }^{1}$, A. A. Kowalski ${ }^{1}$, L. Badinga ${ }^{1}$, R. Pershing ${ }^{1}$, \\ J. Bartolome ${ }^{1}$ and J. E. P. Santos ${ }^{4}$
}

${ }^{1}$ Department of Animal Sciences, University of Florida, PO Box 110910, Gainesville, FL 32611-0910, USA; ${ }^{2}$ Department of Biochemistry, Veterinary Faculty, Montevideo, Uruguay; ${ }^{3}$ Department of Veterinary Medicine, Faculty of Agriculture, Kagoshima University, Japan; and ${ }^{4}$ Veterinary Medicine Teaching and Research Centre, University of California-Davis, Tulare, CA 93274, USA

Evidence is presented that bovine somatotrophin (bST) treatment of lactating dairy cows enhances both expression of oviductal insulin-like growth factor II (IGF-II) mRNA and endometrial insulin-like growth factor binding protein 3 (IGFBP-3) mRNA between day 3 and day 7 of the oestrous cycle, mRNA encoding growth hormone $(\mathrm{GH})$ receptor in endometrial tissues increased between day 3 and day 7 of the oestrous cycle. The changes induced by bST treatment may contribute to stimulation of embryo development and increase pregnancy rates in lactating dairy cows. Additive effects of bST and rb interferon $\tau$ (rbIFN $-\tau$ ) to inhibit phorbol ester induction of prostaglandin $\mathrm{F}_{2 \alpha}$ secretion in immortalized bovine endometrial cells indicates that there is interplay between their signal transduction pathways. Non-lactating dairy cows were killed at day 17 after oestrus to evaluate the effects of pregnancy status (cyclic versus pregnant) and bST (bST versus control) treatment on endometrial gene expression. Distinctly different mRNA and protein responses were detected between cyclic and pregnant cows that were related to luteolytic-antiluteolytic drive (that is expression of progesterone receptor, oxytocin receptor, oestradiol receptor $\alpha$ and prostaglandin GH synthase 2 (PGHS-2)). The bSTinduced changes in PGHS-2 protein ( + ), oxytocin receptor mRNA $(+)$ and oestrogen receptor $\alpha$ protein $(+)$ may potentially affect the mechanisms associated with maintenance of pregnancy. Two experiments were conducted to evaluate whether ovarian follicular suppression induced by biodegradable deslorelin implants would reduce either early or late embryo losses. A $450 \mu \mathrm{g}$ deslorelin implant used to induce ovulation in a timed insemination programme decreased subsequent follicular development and tended to reduce early embryo losses, whereas a $2.1 \mathrm{mg}$ deslorelin implant failed to reduce late embryonic losses when inserted on day 27 of pregnancy. 


\section{Introduction}

Reproductive performance in dairy cattle has declined in association with increased milk production (Lucy, 2001). Owing to alterations in metabolic state associated with lactation and management of high producing cows, the occurrence and intensity of oestrus as well as embryo survival have been reduced. Major advances have been made in the control of ovarian follicular development, ovulation and corpus luteum function that permit insemination at a fixed time without the need to detect oestrus (Burke et al., 1996; Pursley et al., 1997). Pregnancy rate for a group of cows is a product of the percentage of cows detected in oestrus and the percentage of cows that became pregnant after insemination at the detected oestrus. Optimized timed insemination programmes allow for a 100\% submission rate and offer alternative systems of reproductive management to complement nutritional and herd health management programmes. Embryo losses are substantial with estimates of early embryo mortality of $20.5-43.6 \%$ with luteolysis occurring before day 24 , and of late embryonic mortality of $8.0-17.5 \%$ with return to oestrus after 24 days (Humblot, 2002). Estimates of pregnancy losses to a timed insemination after an initial positive diagnosis of pregnancy at approximately day 32 and a second diagnosis at approximately day 74 was $14.6 \%$ (Moreira et al., 2001). Thus, the combination of early and late embryo losses may be about $40 \%$. An experimental advantage of timed insemination programmes is that they allow investigators to focus on strategies to improve embryo survival after an insemination associated with a well-synchronized oestrus or to a timed ovulation. Variability in pregnancy rates associated with errors in oestrus detection is minimized and provides a greater experimental sensitivity in examining factors that may improve pregnancy rates. For example, exogenous administration of bovine somatotrophin (bST) increased pregnancy rates when administered as part of a timed Al protocol in cyclic lactating dairy cows (Moreira et al., 2000, 2001; Santos et al., 2002a) or in protocols involving cows that were inseminated at detected oestrus (Morales et al., 2001; Santos et al., 2002a). Furthermore, pregnancy losses did not differ between timed insemination and insemination after observed oestrus (Santos et al., 2002a). The observation in lactating dairy cows that pregnancy rates were improved and did not differ among control recipients receiving $\mathrm{bST}$-treated embryos and $\mathrm{bST}$-treated recipients receiving control embryos at day 7 after oestrus (Moreira et al., 2002) implied that bST treatment, acting directly or indirectly via a stimulation in the insulin-like growth factor (IGF) system, is essential for early blastocyst development and embryonic growth. The focus of this review is to characterize the responsiveness of the oviduct and uterus to bST at different reproductive windows that are associated with early embryo development and subsequent maintenance of pregnancy. The interacting effects of cyclic pregnancy with exposure to bST on cellular and endocrine responses require investigation, as treatment with bST results in higher pregnancy rates. Other strategies to reduce embryo losses involving regulation of follicle development will be examined.

\section{Effect of bST on oviductal and endometrial IGF system in lactating dairy cows}

On the basis of observations that bST stimulates both pregnancy rates and early embryo development in vitro, an experiment was designed to characterize the responsiveness of the IGF system to bST within the bovine oviduct and uterus during the period of early embryo development on day 3 and day 7 after ovulation. Holstein cows $(n=21)$, producing milk on average for 80 days, were assigned randomly to receive bST (Posilac ${ }^{(\mathbb{1})}, 500 \mathrm{mg} ; n=11$ ) or to serve as untreated controls $(n=10)$ to examine the effect of exogenous bST on oviductal and uterine genes encoding components of the IGF system when administered at $16 \mathrm{~h}$ after the second GnRH injection in an Ovsynch/TAI protocol (Pershing et al., 2001). Within each 
treatment group, cows were killed on day 3 or day 7 of the oestrous cycle. Oviducts and uterine horns ipsilateral to the corpus luteum were trimmed free of the broad ligament, and samples of oviductal and intercaruncular endometrial tissue were collected and frozen immediately at $-80^{\circ} \mathrm{C}$ for subsequent mRNA analyses. The mRNAs encoding IGF-II, IGF binding protein 2 (IGFBP-2) and IGFBP-3 were evident in all northern blots for oviductal and endometrial tissues. Both IGF-l and growth hormone receptor (GHR) mRNAs were detected in the uterus, but not in the oviduct (Table 1). IGF-I mRNA tended to increase in the endometrium at day 7 , but treatment with bST had no detectable effect on the abundance of JGF-I transcript in the uterine endometrium. The steady-state concentration of mRNA encoding IGF-II was induced by bST in oviducts at both day 3 and day 7 and downregulated in endometrium at day 7 . The abundance of IGFBP-2 mRNA transcript was greater in endometrial than in oviductal tissues and did not differ between treatments. Both oviductal and endometrial mRNA encoding IGFBP-3 increased between day 3 and day 7 of the oestrous cycle, and there was a tendency for a greater abundance of endometrial IGFBP-3 mRNA in cows treated with bST at day 7 of the oestrous cycle (Table 1). At day 7 of the oestrous cycle, mRNA encoding endometrial GHR was decreased by $30 \%$ in bST-treated cows. Treatment with bST appeared to stimulate uterine content of IGF-I at day 7 but not at day 3 of the oestrous cycle. Appreciably higher amounts of protein were recovered from the uterine lumen than the oviduct, and protein content decreased between day 3 and day 7 in the uterus, perhaps associated with increased protease activity.

These responses indicate that exogenous bST induces oviductal IGF-II mRNA as early as day 3 of the oestrous cycle, and that IGF-II may play a modulatory role in oviductal differentiation and early embryonic development in cattle. The observation that bST downregulated IGF-II transcript in the endometrium at day 7 of the oestrous cycle, when IGF-I transcript increased between day 3 and day 7 in the endometrium, infers that bST regulation is not only tissuespecific (that is, oviduct versus uterus), but is also causing a differential regulation of ICF-I versus IGF-II. These mitogenic hormones may have either overlapping or distinct roles in the control of embryo cleavage and ensuing blastocyst development. Indeed at day 7 , the luminal content of IGF-1 in the endometrium was increased in response to bST. The physiological significance of bST-induced IGFBP-3 transcript in the uterine endometrium at day 7 of the oestrous cycle warrants further investigation, because bST appears to upregulate IGFBP-3 gene expression at a stage of the oestrous cycle when uterine luminal IGFBPs undergo substantial proteolytic cleavage (data not presented). It is also clear that total luminal protein is reduced by day 7 (Table 1). Collectively, these findings imply complex and tissue-specific regulation of the uterine IGF system components by exogenous bST that may contribute to fertility responses induced by bST in lactating dairy cows. This finding is further supported by the observations that both GH and IGF-I stimulate blastocyst development in vitro (Moreira et al., 2002). However, it is important to recognize that the effects induced by bST may differ between dairy cows that are under homeoretic challenges associated with lactation versus the nonlactating dairy cow. The IGF system is involved markedly in regulating functions of the ovary (Lucy, 2000), oviduct (Pushpakumara et al., 2002), uterus and placental development (Wathes et al., 1998) in ruminants, and may contribute to autocrine and paracrine interrelationships in early pregnancy.

\section{Effects of bST and pregnancy status on endocrine responses and endometrial gene expression in non-lactating dairy cows}

There is substantial evidence for cross-talk between hormonal signal transduction systems, such as oestrogen receptor $\alpha$ and IGF-I (Klotz et al., 2002), and bST effects on fertility may 
W. W. Thatcher et al.

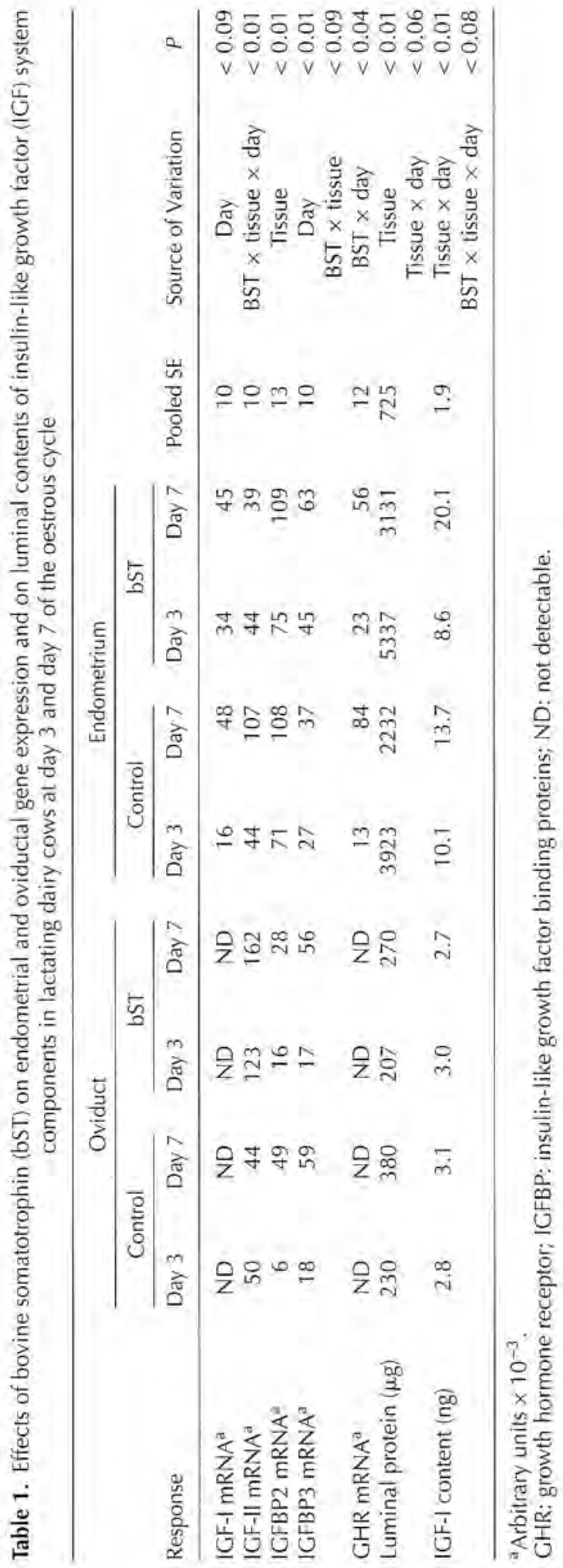


involve an interaction between bST and interferon $\tau$ (IFN- $\tau$ ) signalling pathways to regulate prostaglandin secretion. Some evidence for such a phenomenon is that treatment of bovine immortalized endometrial cells with phorbol ester increases prostaglandin $\mathrm{F}_{2 \alpha}\left(\mathrm{PGF}_{2 \alpha}\right)$ secretion and prostaglandin GH synthase 2 (PGHS-2) gene expression (Binelli et al., 2000). Badinga et al. (2002) demonstrated that preincubation of cell monolayers with rbIFN- $\tau$ suppressed $\mathrm{PGF}_{2 \alpha}$ and PGHS-2 mRNA responses to phorbol ester. However, a co-preincubation with $\mathrm{rbGH}$ and rbIFN- $\tau$ induced an additive inhibitory effect on $\mathrm{PGF}_{2 \alpha}$ secretion. This synergism between $\mathrm{GH}$ and rbIFN- $\tau$ infers that these molecules may affect the $\mathrm{PGF}_{2 \alpha}$ cascade through distinct signal transduction pathways particularly as the attenuation in $\mathrm{PGF}_{2 \alpha}$ secretion due to $\mathrm{GH}$ preincubation alone did not alter PGHS-2 mRNA responses to phorbol ester (Badinga et al., 2002). The potential for downstream responses to bST and the IGF family to influence sensitivity of cellular systems via alterations in receptor dynamics or influencing signal transduction systems in different physiological states (for example lactation and pregnancy) has profound implications relative to regulating production responses (for example, follicle development, embryo survival and milk production).

An experiment was designed to examine the effects of pregnancy status and bST on uterine gene expression and function (Guzeloglu et al, 2002). Non-lactating cows were either inseminated $(n=31$ ) or not inseminated (cyclic, $n=14$ ) to a timed ovulation (day 0 ) following an Ovsynch programme in which GnRH $\left(100 \mu \mathrm{g}\right.$, i.m., Cystorelin ${ }^{(1)}$; Merial Ltd, Iselin, NJ) was injected on day -10 followed 7 days later (day -3$)$ by an injection of $\mathrm{PGF}_{2 \alpha}(25 \mathrm{mg}$, i.m., Lutalyse ${ }^{\circledR}$; Pharmacia Corp., Kalamazoo, MI). At 48 h after injection of $\mathrm{PGF}_{2 \alpha}, \mathrm{GnRH}$ (day -1) was administered followed by insemination $16 \mathrm{~h}$ later for the pregnant cow group. Cows either received bST ( $n=28$; day 0 and day $11,500 \mathrm{mg}$, Posilac, Monsanto Co., St Louis, $\mathrm{MO})$ or did not receive bST $(n=17)$. On day 17 , cows were killed and uteri were flushed to recover secretions and conceptuses. Endometrial tissues were collected from the uterine horn ipsilateral to the corpus luteum for protein and mRNA analyses and immunocytochemical evaluation. Pregnancy rate to the timed insemination was reduced in the bST-treated cows in which conceptuses were recovered from four of 21 cows $(19 \%)$ compared with six of ten $(60 \%)$ control $(P<0.01)$ cows. In conceptuses that were recovered, length was greater in bSTtreated cows $(49.7 \pm 7.0 \mathrm{~cm}>24.5 \pm 5.0 \mathrm{~cm} ; P<0.02)$. Additional replications resulted in estimates of accumulated pregnancy rate $(9$ of 33 bST $(27.2 \%)$ and 14 of 22 control $((63.6 \%)$, $P<0.01$ ) and conceptus length (bST > control: $39.2 \pm 4.8 \mathrm{~cm}>20.0 \pm 4.3 \mathrm{~cm} ; P<0.01$ ) that reflect the initial experimental observations. It is clear that in non-lactating multiparous dairy cows, there was a reduction in fertility. It is important to recognize that in addition to using experimental cows that were non-lactating, cows were also injected twice with bST at an interval of 11 days. This procedure was performed to ensure that there was sustained exposure to bST for the entire 17 day period up to slaughter. In lactating cows that were treated with bST (500 mg Posilac ${ }^{\circledR}$ at 2 week intervals), fertility was increased (Moreira et al., 2001). Treatment with bST each day $(25 \mathrm{mg}$ i.m. each day) stimulated follicle development (number of follicles of $6-9 \mathrm{~mm}$ in diameter) during the first follicular wave to that of non-lactating control cows (De la Sota et al., 1993). However, prolonged continuous infusions of bST (29 mg day $^{-1}$ ) for 63 days resulted in stimulation of follicular development based on an increase in the number of corpora lutea, oestrogen active follicles and the proportion of cows with five or more follicles $>5 \mathrm{~mm}$ in diameter at day 5 of the oestrous cycle (Jimenez-Krassel et al., 1999). Thus, it is possible that over-stimulation with bST may have distinct physiological effects, and the dosing regimen used in the present experiment with non-lactating cows contributed to a reduction in fertility.

Plasma concentrations of progesterone were measured in 22 cows each day from the day of $\mathrm{GnRH}$ injection (day 0 ) to day 17 when the non-lactating dairy cows were killed. 


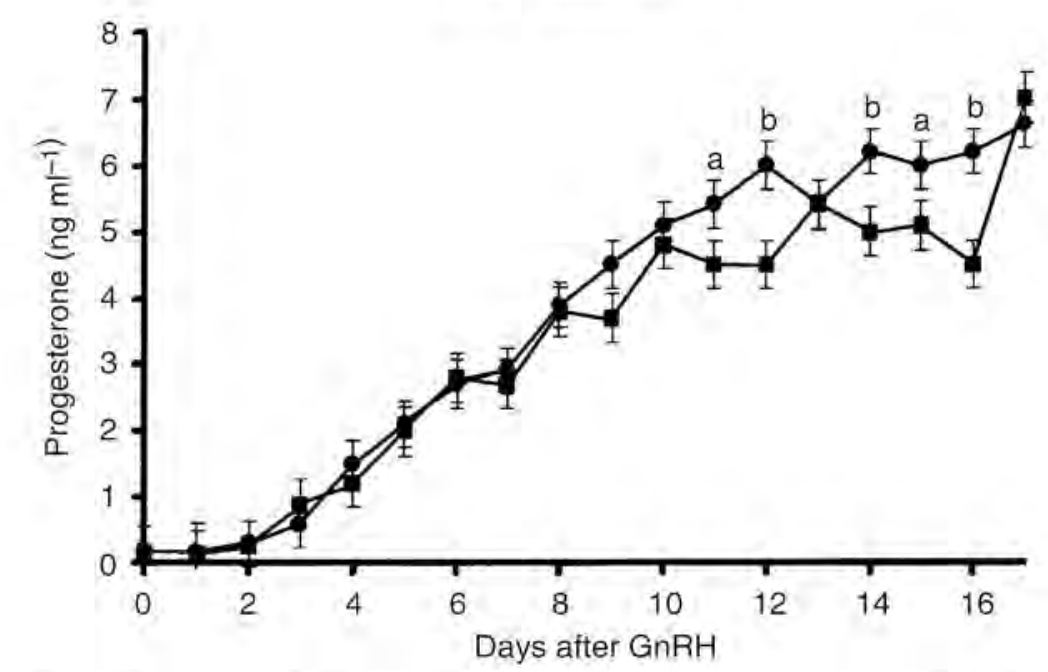

Fig. 1. Profiles of plasma concentrations of progesterone from day 0 to day 17 after a synchronized ovulation induced by GnRH in cows confirmed pregnant ( or cyclic $(\bullet)\left({ }^{a} P<0.10 ;{ }^{b} P<0,05\right)$.

Table 2. Oligonucleotide primers for cloning bovine oxytocin receptor (OTR), prostaglandin $E$ synthase (PGES) and progesterone receptor (PR) CDNAS

\begin{tabular}{|c|c|c|c|}
\hline CDNA & Primer set & Size (bp) & GenBank accession number \\
\hline OTR & $\begin{array}{l}\text { F } 5^{\prime} \text { GCACCTGAGCATAGCCGACC } 3^{\prime} \\
\text { R } 5^{\prime} \text { GTGGCAAGGACGATGACGGG } 3^{\prime}\end{array}$ & 397 & AFT01724 \\
\hline PGES & $\begin{array}{l}\text { F } 5^{\prime} \text { GCGCGCTGCTGGTCATCAAA } 3^{\prime} \\
\text { R } 5^{\prime} \text { GTGTAGGCCAGGGAGCGGGT } 3^{\prime \prime}\end{array}$ & 314 & AY032727 \\
\hline PR & $\begin{array}{l}\text { F } 5^{\prime} \text { TCTGGAAATTCAACACTCAG } 3^{\prime} \\
\text { R } 5^{\prime} \text { GCTICAAGTCAGCCAAGAAG } 3^{\prime}\end{array}$ & 291 & AY116891 \\
\hline
\end{tabular}

There were no differences in plasma progesterone concentrations up to day 10 between cyclic and pregnant cows. However, after day 10, pregnant cows appeared to have lower progesterone concentrations (Fig. 1). This progesterone profile is in contrast to previous studies on lactating dairy cows demonstrating that a late post-ovulatory increase and low luteal phase concentrations of progesterone occurred in cows that failed to become pregnant (Mann et al., 1999). In the present study, the timed insemination protocol, involving the use of $\mathrm{GnRH}$ to induce ovulation precisely, was used to ensure that ovulation was synchronized. Formation of the corpus luteum was confirmed by ultrasonography. With well-synchronized ovulations in non-lactating dairy cows, we failed to detect any differences in the post-ovulatory increase in progesterone. The lower plasma progesterone concentration in the later luteal phase of pregnant cows may reflect a greater clearance rate of progesterone by the uterus under the influence of a conceptus or a pregnancy-induced attenuation in progesterone secretion by the corpus luteum. Treatment with bST failed to have any effect on plasma progesterone concentrations.

Complementary DNA was transcribed from total RNA prepared from the bovine corpus luteum. A set of primers (Forward and Reverse; Table 2) was synthesized based collectively on conserved sequences from bovine oxytocin receptor and prostaglandin E synthase (PGES) 
Table 3. Least squares means for uterine endometrial expression responses at day 17 after oestrus in non-lactating cyclic or pregnant dairy cows $(n=30)$ injected with or without bovine somatotrophin (bST) on day 0 and day 11 after oestrus

\begin{tabular}{|c|c|c|c|c|c|c|c|c|}
\hline \multirow[b]{3}{*}{ Response } & \multicolumn{5}{|c|}{ Treatments } & \multirow{2}{*}{\multicolumn{3}{|c|}{ Contrasts }} \\
\hline & & & & & & & & \\
\hline & Cyclic & Pregnant & bST & bST & SE & Status ${ }^{\mathrm{a}}$ & bST & Status $\times$ bST \\
\hline $\begin{array}{l}\text { Plasma progesterone } \\
\left(\mathrm{ng} \mathrm{ml}^{-1}\right)\end{array}$ & 6.9 & 5.1 & 6.4 & 5.3 & 0.66 & $P<0.05$ & NS & NS \\
\hline PR mRNA (AU) & 137 & 140 & 147 & 147 & 1.3 & NS & $P<0.01$ & NS \\
\hline PR protein gland ${ }^{b}$ (SA) & 1.25 & 1.91 & 1.44 & 1.64 & 0.11 & $P<0.01$ & NS & $P<0.06$ \\
\hline PR protein stroma ${ }^{b}(S A)$ & 1.27 & 1.30 & 0.85 & 1.02 & 0.15 & NS & $P<0.03$ & NS \\
\hline$E R \propto m R N A(A U)$ & 156 & 149 & 152 & 131 & 4.6 & $P<0.01$ & $P<0.03$ & $P<0,12$ \\
\hline ERa protein (AU) & 161 & 130 & 176 & 149 & 9.6 & $P<0.01$ & $P<0.08$ & NS \\
\hline$E R \alpha$ lumen $^{b}$ (SA) & 1.71 & 1.40 & 1.54 & 1.34 & 0.10 & $P<0.05$ & NS & NS \\
\hline OTR mRNA (AU) & 108 & 111 & 150 & 129 & 5.7 & NS & $P<0.01$ & $P<0.04$ \\
\hline PGHS-2 mRNA (AU) & 166 & 176 & 171 & 164 & 11 & NS & NS & NS \\
\hline PGHS-2 protein (AU) & 43.5 & 69.7 & 56.3 & 97 & 9.4 & $P<0.01$ & $P<0.03$ & NS \\
\hline PGFS mRNA (AU) & 126.8 & 128.6 & 125.3 & 127.7 & 5.9 & NS & NS & NS \\
\hline PGES MRNA (AU) & 135.6 & 129.1 & 138.3 & 137.1 & 3.0 & NS & $P<0.10$ & NS \\
\hline
\end{tabular}

a Status: Pregnancy versus cyclic.

${ }^{\mathrm{h}} n=22$ cows.

mRNA results are adjusted for GAPDH as a covariate.

AU: Arbitrary units were generated by densitometry.

SA: Staining (immunohistochemical) intensity weighted average for luminal oestrogen receptor $\alpha$ (ER $\alpha$ ), glandular or stromal progesterone receptor $(P R)$ proteins $(0=$ No, $1=$ less, $2=$ moderate and $3=$ heavy staining).

OTR: oxytocin receptor; PGHS-2: prostaglandin growth hormone synthase 2; PGFS; prostaglandin F synthase; PGES: prostaglandin Esynthase.

mRNAs as well as sheep and pig progesterone receptor mRNAs. The primers were used in PCR amplification with cDNA template. The expected cDNA fragments were subcloned and the nucleotide sequences compared with respective gene sequences reported in GenBank. The bovine PGHS-2 (Liu et al., 2001; GenBank accession number AF031698) and prostaglandin F synthase (PGFS; Xiao et al., 1999) cDNAs were gifts from J. Sirois (Université de Montreal, St-Hyacinthe, Quebec). The oestrogen receptor $\alpha$ cDNA (Ing et al., 1996) was a gift from N. H. Ing (Texas A\&M University, College Station, TX). The radiolabelled cDNAs were used for northern blot analyses of respective mRNAs. Specific polyclonal antibodies (PGHS-2, Cayman Chemical, Ann Arbor, MI; oestrogen receptor $\alpha$, Santa Cruz, CA; progesterone receptor, Zymed Laboratories, San Francisco, CA) and non-immune serum were used for western blot analysis and immunohistochemistry.

In 30 cows (cyclic $(n=7)$, pregnant $(n=7)$, cyclic-bST $(n=7)$ and pregnant-bST $(n=9)$ ), oestrogen receptor $\alpha$, progesterone receptor, oxytocin receptor, PGHS-2, PGFS, PGES mRNAs, oestrogen receptor $\alpha$ protein, PGHS-2 protein and immunohistochemical-spatial localization of oestrogen receptor- $\alpha$ protein and progesterone receptor protein were quantified in the endometrium (Table 3). Treatment with bST increased steady-state concentrations of progesterone receptor mRNA in endometrial tissue. Spatial differences were detected in which progesterone protein staining of uterine glands was high in pregnancy but the increase in staining between cyclic and pregnant cows was greater in cows that were not treated with bST (Table 3). In the luminal epithelium of the intercaruncular region, progesterone receptor staining was negative, whereas some positive cells were found in the caruncle. Staining intensity of progesterone receptor protein was greater in the deep glands compared with superficial 
glands. In contrast, progesterone receptor protein staining in the stroma was not influenced by pregnancy status but was reduced in cows treated with bST. Overall, progesterone receptor protein staining was greater in the superficial than in the deep stroma.

Endometrial oestrogen receptor $\alpha$ mRNA, as measured by northern blot analysis, was high (Table 3; $P<0.01$ ) in cyclic cows at day 17 , and bST treatment further reduced oestrogen receptor $\alpha$ mRNA content in pregnant cows (Table $3 ; P<0.03$ ). A further quantification of mRNA using the technique of solution hybridization in a sub-sample of 22 cows, with the same oestrogen receptor $\alpha$ probe, verified that cyclic cows had higher endometrial oestrogen receptor $\alpha$ mRNA $\left(0.602 \pm 0.046>0.421 \pm 0.05 \mathrm{fmol} \mathrm{mg}^{-1}\right.$ total nucleic acid; $\left.P<0.02\right)$. This finding was substantiated by increased staining intensity for oestrogen receptor $\alpha$ protein in luminal epithelial cells $(P<0.05)$, as well as increased overall oestrogen receptor $\alpha$ protein in endometrial tissue lysates of cyclic versus pregnant cows $(P<0.01)$. Heavy staining for the oestrogen receptor $\alpha$ protein was detected in deep endometrial glands $(P<0.01)$ compared with superficial and medium glands irrespective of bST treatment and pregnancy status (data not shown). An interesting main effect of bST $(P<0.08)$ was detected for oestrogen receptor $\alpha$ protein in endometrial tissue lysates indicating that bST possibly enhanced translation rate into oestrogen receptor $\alpha$ protein (Table 3). However, even in bST-treated cows with high amounts of oestrogen receptor $\alpha$ protein, the responses were greater in cyclic cows $(P<0.01)$. Treatment with GH increased both cytoplasmic and nuclear oestrogen receptor content in the guinea-pig uterus (Bezecny et al., 1992).

Steady-state concentrations of oxytocin receptor mRNA were higher in bST-treated cows $(P<0.01)$, and the interaction of bST $\times$ status $(P<0.04)$ indicated oxytocin receptor mRNA steady state concentration was higher in bST-treated cyclic cows (Table 3). An increase in mRNAs encoding oxytocin receptor and oestrogen receptor $\alpha$ in cyclic cows in comparison with pregnant cows at day 17 after oestrus is in agreement with the results of Robinson et al. (2001).

A dichotomy of responses is evident regarding bST effects. In non-lactating cows, bST reduced pregnancy rate, as evident in this study, compared with increased pregnancy rates in lactating cows (Moreira et al., 2000, 2001; Santos et al., 2002a). Among the uterine responses in the present study, expression of oestrogen receptor $\alpha$ gene was reduced in bST-treated animals, which would be compatible with a potentially greater anti-luteolytic mechanism. In contrast, the amount of oestrogen receptor $\alpha$ protein was increased in endometrial tissue of bST-treated cows and may have contributed to the lower pregnancy rate.

The differential regulation of prostaglandin secretion between the cyclic and pregnant status is pivotal to our understanding of pregnancy-induced effects and the response of these states to a factor such as bST that appears to have associated effects on fertility. Pregnant cows had higher concentrations of $\mathrm{PGF}_{2 \alpha}$ and $\mathrm{PGE}_{2}$ in uterine flushings $\left(\mathrm{PGF}_{2 \alpha}\right.$, $619 \pm 95>109 \pm 51 \mathrm{ng}, P<0.01 ; \mathrm{PGE}_{2}, 86 \pm 12>12 \pm 7 \mathrm{ng}, P<0.01$ ). There was no major difference in steady state concentrations of PGHS-2 mRNA due to pregnancy state or bST treatments. However, PGHS-2 protein was increased due to both pregnancy $(P<0.01)$ and bST $(P<0.03)$ treatments (Table 3$)$. The bST-induced increase in PGHS-2 protein parallels a comparable bST-induced increase in oestrogen receptor $\alpha$ protein as a main effect. Although endometrial tissues from pregnant and bST treatments had increased masses of PGHS-2 protein as measured by western blot analysis, it is important to determine the responses of PGFS and PGES mRNAs (that is, relative gene expression that may or may not be related to enzymatic protein or activity) regarding potential downstream metabolism of $\mathrm{PGH}_{2}$. Indeed, if PGHS-2 protein is increased in pregnancy then downstream melabolism to PGF $_{2 \alpha}$ should be reduced in pregnancy. Relative expression of PGFS mRNA did not differ among all the treatments. There was no evidence for an upregulation of PGES mRNA in 
early pregnancy, and it tended to be higher in bST-treated cows $(P<0.10)$. Collectively, the present responses imply that either inhibition of PGHS activity or differential metabolism of $\mathrm{PGH}_{2}$ to products with a less luteolytic drive (that is, decreased $\mathrm{PGF}_{2 \alpha}$ secretion) may be in operation.

In the luteolytic cascade, oestrogen receptor $\alpha$ mRNA was positively correlated with PGHS2 mRNA $(r=0.55, P<0.01$; partial $r=0.58, P<0.01)$ and negatively correlated with progesterone receptor mRNA $(r=-0.47, P<0.01$; partial $r=-0.54, P<0.01)$. An increase in the content of oxytocin receptor $\mathrm{mRNA}$ was associated with an increase in progesterone receptor mRNA ( $r=0.38, P<0.03$; partial $r=$ not significant). Kombe et al. (2002) demonstrated a greater $\mathrm{PGF}_{2 \alpha}$ secretory response to oestrogen receptor in progesterone-primed bovine endometrial epithelial cells.

Pregnancy induced an increase in PGHS-2 protein in the endometrium, although expression of PGHS-2 mRNA did not change. Similar results were reported in sheep as pregnancy increased PGHS-2 protein but not PGHS-2 mRNA content (Charpigny et al., 1997). These results may indicate pregnancy-associated increases in translation efficiency of PGHS-2 protein in the presence of steady state concentrations of mRNA. In contrast, Kim et al. (2002) reported that pregnancy induced an increase in mRNA expression for PGHS-2 in sheep.

\section{Response of primary cultures of day 17 endometrial epithelial cells to rbIFN- $\tau$}

Characterization of the differences in endometrial regulation of prostaglandin secretion between cyclic and pregnant cows and the potential influence of other regulatory systems on the luteolytic-antiluteolytic system is vital for the development of programmes to stimulate reproductive performance. Cultures of primary endometrial epithelial cells from day 15 of the oestrous cycle indicate that rbIFN- $\tau$ decreased $\mathrm{PGF}_{2 \alpha}$ secretion either in the presence or absence of oxytocin (Danet-Desnoyers et al., 1994). In primary cultures of endometrial epithelial cells established from cows during days 1-3 of the oestrous cycle, Asselin et al. (1998) demonstrated that high doses of rbIFN- $\tau$ stimulated PGF $F_{2 \alpha}$ secretion and low doses of rblFN- $\tau$ decreased $\mathrm{PGF}_{2 \alpha}$ secretion. Furthermore, Asselin et al. (1998) proposed that rbIFN- $\tau$ caused a preferential secretion of $\mathrm{PGE}_{2}$ that may be important for maintenance of pregnancy.

In a sub-sample of seven cyclic cows at day 17 of the oestrous cycle, endometrial epithelial cells were isolated from the uterine horn contralateral to the ovary bearing the corpus luteum and cultured in a serum-free Dulbecco's modifield Eagle's medium-F12 media until $90 \%$ confluent. Epithelial cells were treated in a factorial design with IFN $-\tau(0,50$ or $500 \mathrm{ng}$ $\mathrm{ml}^{-1}$ ) and phorbol 12,13 dibutyrate (PdBu: 0 or $100 \mathrm{ng} \mathrm{ml}^{-1}$ ) and media were collected after $24 \mathrm{~h}$ for measurement of $\mathrm{PGF}_{2 \alpha}$ and $\mathrm{PGE}_{2}$ in the conditioned culture media. Treatment with $\mathrm{PdBu}$ induced $\mathrm{PGF}_{2 \alpha}$ secretion $(P<0.01)$, and $\mathrm{IFN}-\tau\left(50\right.$ and $\left.500 \mathrm{ng} \mathrm{ml}^{-\mathrm{I}}\right)$ caused a reduction in $\mathrm{PGF}_{2 \alpha}$ secretion induced by $\mathrm{PdBu}(P<0.01$; Fig. 2$)$. In the absence of $\mathrm{PdBu}$, rblFN- $\tau$ caused an increase in basal secretion of $P G F_{2 \alpha}(P<0,02)$. Secretion of $P G E_{2}$ was lower than that of $\mathrm{PGF}_{2 \alpha}\left(\mathrm{PGE}_{2}: \mathrm{PGF}_{2 \alpha}<1\right)$. Concentrations of $P G E_{2}$ increased in response to $\mathrm{PdBu}(P<0.05)$, and $50 \mathrm{ng}$ IFN- $\tau \mathrm{ml}^{-1}$ had a slight stimulatory effect on $\mathrm{PGE}_{2}$ concentrations compared with the $500 \mathrm{ng} \mathrm{ml}^{-1}$ doses $(P<0.05)$ either in the presence or absence of $\mathrm{PdBu}$ (Fig. 2). The changes in $\mathrm{PGF}_{2 \alpha}$ secretion imply a differential effect in that rblFN $-\tau$ stimulates basal secretion of $\mathrm{PGF}_{2 \alpha}$ perhaps through a type I IFN receptor activated system. Type I IFNs have been shown to activate downstream molecules including $N F_{\kappa} B$ (Yang et al., 2001) which induces PGHS-2 gene transcription through its potential binding site on the PGHS-2 gene promoter (Kelly et al., 2001; Thatcher et al., 2001). However, with post-receptor activation of protein kinase $\mathrm{C}$ (that is, $\mathrm{PdBU}$ activation), rbIFN- $\tau$ reduced $\mathrm{PGF}_{2 \alpha}$ secretion. 
(a)

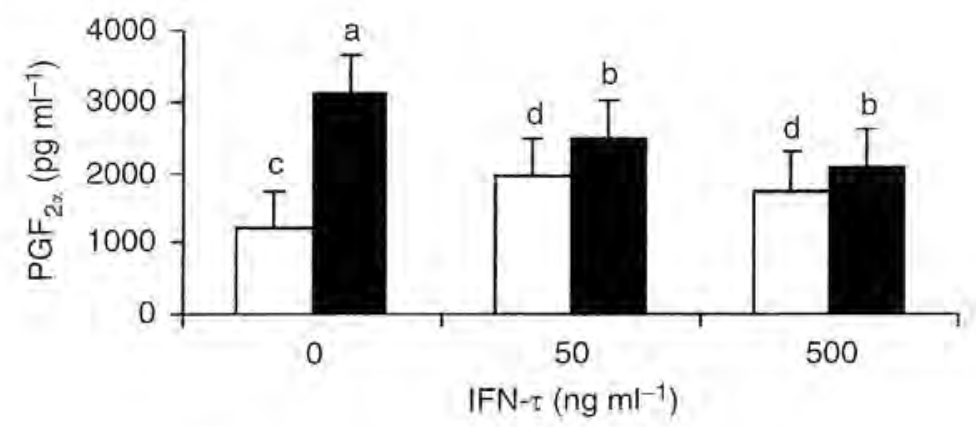

(b)

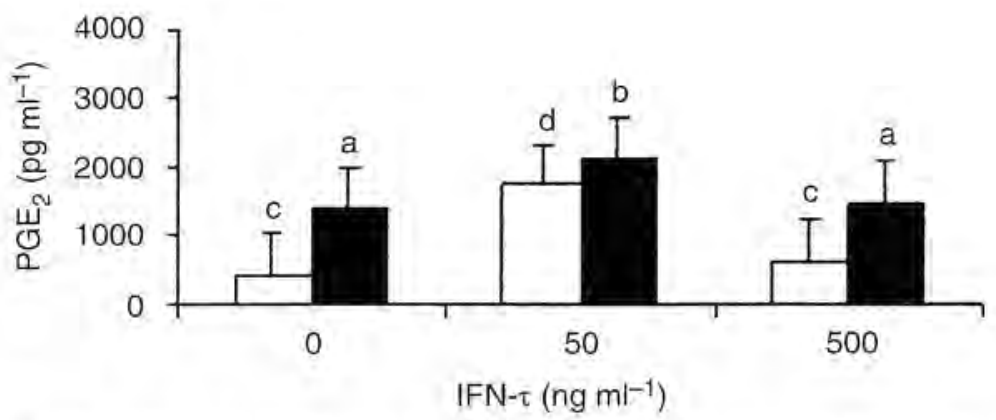

Fig. 2. Effect of phorbol 12,13-dibutyrate (PdBu) and $\mathrm{rb}$ interferon $\tau$ (rbIFN- $\tau$ ) on (a) prostaglandin $F_{2 \alpha}\left(P G F_{2 \alpha}\right)$ and (b) prostaglandin $E_{2}\left(P G E_{2}\right)$ secretion in primary culture of bovine endometrial cells from seven cows at day 17 after oestrus. Cultures of serum-starved endometrial epithelial cells were treated with PdBu $\left(100 \mathrm{ng} \mathrm{ml}^{-1}\right)$ ( or control ( $\square$ ) and with either 0,50 or $500 \mathrm{ng}$ rbIF $\mathrm{N}-\tau \mathrm{ml}^{-1}$ for $24 \mathrm{~h}$. Each treatment combination within a cow was repeated three times and least squares means \pm SEM are presented. Superscripts a versus b represent differences among rbIFN- $\tau$ treatments for $\mathrm{PdBu}(P<0.05)$, whereas superscripts $\mathrm{C}$ versus d indicate differences among rbIFN- $\tau$ treatments for control (that is, $\mathrm{PGF}_{2 \alpha}, P<0.02$; $\mathrm{PGE}_{2}, P<0.05$ ).

This response was similar to but not as inhibitory as that observed with a bovine immortalized endometrial cell line (Binelli et al ${ }_{+}$2000). Oxytocin acts through a seven-transmembrane receptor coupled to a $\mathrm{G}$ protein activation of phospholipase $\mathrm{C}$ that ultimately activates protein kinase C (PKC) via increases in intracellular $\mathrm{Ca}^{2+}$ and diacylglycerol (Thatcher et al., 2001). Present results indicate that rbIFN- $\tau$ attenuates PKC activation of $\mathrm{PGF}_{2 \alpha}$ secretion in primary culture of epithelial cells and supports earlier observations of an rbIFN- $\tau$ attenuation of oxytocin induced secretion of $\mathrm{PGF}_{2 \alpha}$ in primary epithelial cells originating from uteri at day 15 of the oestrous cycle (Danet-Desnoyers et al., 1994).

\section{Strategies for reducing early and late embryo mortality}

There are four lines of evidence indicating that regulation of ovarian function after insemination may improve embryo survival. Normăl ovarian follicular development is regulated locally during early pregnancy and follicular development is somewhat attenuated in early 
Table 4. Reproductive responses of lactating dairy cows to a Presynch-Ovsynch programme using deslorelin implants $(450 \mu \mathrm{g}$ and $750 \mu \mathrm{g})$ or $\mathrm{GnRH}$ injection to induce ovulation

\begin{tabular}{|c|c|c|c|}
\hline \multirow[b]{2}{*}{ Response } & \multirow{2}{*}{$\frac{\text { GnRH control }}{100 \mu \mathrm{g}}$} & \multicolumn{2}{|c|}{ Deslorelin implants } \\
\hline & & $450 \mu g$ & $750 \mu \mathrm{g}$ \\
\hline Number of cows & 293 & 150 & 153 \\
\hline Pregnancy rate (\%) at day 27 & $39.0^{\mathrm{a}}$ & $40.0^{+1}$ & $27.5^{b}$ \\
\hline Pregnancy rate $(\%)$ at day 41 & $33.5^{\mathrm{a}}$ & $38.0^{3}$ & $24.8^{\mathrm{b}}$ \\
\hline Pregnancy loss $(\%)$ at days $27-41$ & $12.7^{c}$ & $5.0^{d}$ & $9.5^{\mathrm{c} d \mathrm{~d}}$ \\
\hline $\begin{array}{l}\text { Number of follicles of } 5-9 \mathrm{~mm} \\
\text { in diameter }\end{array}$ & $2.10 \pm 0.18^{a}$ & $0.89 \pm 0.24^{b}$ & $0.94 \pm 0.17^{15}$ \\
\hline $\begin{array}{l}\text { Number of follicles of } 10-19 \mathrm{~mm} \\
\text { in diameter }\end{array}$ & $1.27 \pm 0.12^{i}$ & $0.58 \pm 0.16^{b}$ & $0.58 \pm 0.11^{6}$ \\
\hline Progesterone at day $11\left(\mathrm{ng} \mathrm{ml}^{-1}\right)$ & $7.08 \pm 0.33$ & $7.01 \pm 0.44$ & $7.75 \pm 0.38$ \\
\hline Pregnancy rate $(\%)$ at second $\mathrm{Al}$ & $25.2^{\text {d }}$ & $16.7^{b}$ & $9.6^{6}$ \\
\hline
\end{tabular}

a.b Values with different superscripts within the same row are significantly different $(P<0,01)$ - $c$ dValues with different superscripts within the same row are significantly different $(P<0.13)$.

pregnancy on the ovary with the corpus luteum that is ipsilateral to the uterine horn bearing the conceptus (Thatcher et al., 1991). On day 17 after oestrus, there is an upregulation of oestrogen receptor $\alpha$ mRNA, oestrogen receptor $\alpha$ protein, oestrogen receptor $\alpha$ protein staining in the luminal epithelium, oxytocin receptor mRNA, and a spatial decrease in progesterone receptor in the uterine glands of cyclic cattle that is not evident in pregnant cows. Normal or aberrant follicular development approaching the time of conceptus signalling may contribute to embryo losses. Induction of an accessory corpus luteum by hCG at day 5 after oestrus in cows induced three follicular waves, high progesterone concentrations (Diaz et al., 1998) and increased pregnancy rates in lactating dairy cows (Santos et al., 2001). On the basis of these reports and observations, a series of experiments was conducted to test the hypothesis that strategic implantation of a deslorelin implant to attenuate ovarian follicular development (Mattos et al., 2001) would reduce either early (Santos et al., 2002b) or late (Bartolome et al., 2002) embryo mortality.

After blocking for lactation, body condition score and milk production, 596 Hólstein cows were assigned randomly to one of two treatments at day $30 \pm 3$ after parturition. Cows received PGF $\mathrm{F}_{2 \alpha}$ injections at days $30 \pm 3$ and $44 \pm 3$ after parturition (Santos et al., 2002b). At day $58 \pm 3$ after parturition, cows received a $\mathrm{GnRH}$ injection followed 7 day later by a $\mathrm{PGF}_{2 \alpha}$ injection. At $48 \mathrm{~h}$ after the last $\mathrm{PGF}_{2 \alpha}$ injection, cows received either a $\mathrm{GnRH}$ injection (100 $\mu \mathrm{g}$ Gonadorelin) or GnRH agonist implants (deslorelin, 450 or $750 \mu \mathrm{g}$; Peptech, Animal Health, North Ryde) and were inseminated 12-16 h later. Pregnancy was diagnosed by ultrasonography at day 27 after $\mathrm{Al}$ and reconfirmed 14 days later. Follicular populations and the presence of corpora lutea were determined for non-pregnant cows at day 27 after Al. Non-pregnant cows at day 27 were re-synchronized with initiation of the Ovsynch protocol at day 27 after $\mathrm{Al}$. Pregnancy rates at day 27 for a total of 596 cows differed between the deslorelin implant groups and the control (Table 4), with the $750 \mu$ deslorelin implant group having a lower pregnancy rate than the $450 \mu \mathrm{g}$ implant group $(P<0.01)$. Pregnancy rates were approximately $40 \%$ for the $\mathrm{GnRH}$ control and the $450 \mu \mathrm{g}$ implant groups. Pregnancy losses between day 27 and day 41 tended to be lower for the $450 \mu \mathrm{g}$ deslorelin implant group than for the $\mathrm{GnRH}$ control $(5.0 \%$ versus $12.7 \%$; $P<0.13$; Table 4$)$. The numbers of follicles that were $5-9 \mathrm{~mm}$ and $10-19 \mathrm{~mm}$ in diameter at the time of pregnancy diagnosis at day 27 (Table 4) were reduced in the deslorelin implant groups indicating that follicular development was attenuated. Indeed, both implant doses reduced the number of non-pregnant 
animals that were re-inseminated by day 27 after $\mathrm{Al}(51.4,28.7$ and $11.7 \%$ for the $\mathrm{GnRH}$ control, 450 and $750 \mu \mathrm{g}$ implant groups, respectively). No differences in luteal phase concentrations of plasma progesterone were detected (Table 4). The trend of reduced pregnancy losses for the $450 \mu \mathrm{g}$ deslorelin implant group supports the concept that follicular development during the period of early embryo development may adversely affect embryo survival. However, the present experimental approach with deslorelin implants had a carry over effect in which delayed follicular development reduced the percentage of cows presented for second service by day $27(51.4,28.7$ and $11.7 \%$ for $\mathrm{GnRH}, 450$ and 750 deslorelin implants, respectively $(P<0.01))$. The delays in return to oestrus were also associated with percentages of cows with a follicle $\geqslant 10 \mathrm{~mm}$ in diameter $(83.1,60.2$ and $45.9 \%$ for GnRH, 450 and 750 deslorelin implants, respectively $(P<0.01)$ ), and with a corpus luteum $(72.9,60.2$ and $49.5 \%$ for $\mathrm{GnRH}, 450$ and 750 deslorelin implants, respectively $(P<0.01))$, at day 27 . These significant responses that were incremental between treatments may be associated with the differences in pregnancy losses to first service between the 450 and 750 ug deslorelin implants. In cows that did not conceive to first service, pregnancy rates to the subsequent second timed insemination were decreased in cows treated with either dose of the Deslorelin implants (Table 4).

A biodegradable $2.1 \mathrm{mg}$ deslorelin implant (Ovuplant, Peptech) was inserted s.c. on day 27 of pregnancy to evaluate whether an induced accessory corpus luteum and suppressed follicular growth may reduce late embryonic mortality, and pregnancy rates were evaluated on day 45 and day 90 in comparison with a control group that did not receive implants. The experiment included pregnant cows $(n=179)$ as detected by ultrasonography on day 27 after insemination. Cows were assigned randomly to receive $(n=89)$ or not to receive (control; $n=90$ ) a deslorelin implant on day 27. On day 27 and day 45 , pregnancy was confirmed by ultrasonography and the numbers of class 2 follicles $(6-9 \mathrm{~mm})$, class 3 follicles $(>10 \mathrm{~mm})$ and corpora lutea were recorded. On day 90, pregnancy was determined by rectal palpation. Blood samples were collected on day 27 and day 45 for progesterone analysis. Pregnancy losses were evaluated after adjustment for parity and number of previous services. Pregnancy losses between day 27 and day 45 were $15.5 \%$ (14 of 90) for control and 20.2\% (18 of 89 ) for deslorelin implant $(\mathrm{OR}=0.8 ; 95 \% \mathrm{Cl}=0.34,1.75 ; P=0.54)$ groups. Overall pregnancy losses (day 27 to day 90) were $24.4 \%$ (22 of 90 ) for control and $25.8 \%$ (23 of 89 ) for the deslorelin implant group. The deslorelin implant group suppressed the number of class 2 $(0.72 \pm 0.19<1.90 \pm 0.18)$ and class $3(0.86 \pm 0.12<1.92 \pm 0.12)$ follicles and increased the number of corpora lutea $(1.80 \pm 0.07>1.31 \pm 0.07 ; P<0.01)$ and plasma progesterone concentrations on day $45\left(8.03 \pm 0.33>6.40 \pm 0.31 \mathrm{ng} \mathrm{ml}^{-1}\right)$. Although a deslorelin implant administered on day 27 of pregnancy was able to reduce follicular growth, increase the number of corpora lutea, and increase plasma progesterone, it failed to increase embryo or fetal survival between day 27 and day 90 of gestation. Collectively, these two experimental approaches, to attenuate follicular development and stimulate plasma progesterone, indicate a period of pregnancy sensitivity regarding early embryo mortality but not late embryonic mortality.

\section{Conclusion}

Treatment of lactating dairy cows with bST resulted in oviductal and endometrial changes in the IGF system that may be conducive to blastocyst development and embryonic growth. There are clear differences in the balance of luteolytic-antiluteolytic drive (that is, expression of progesterone receptor, oxytocin receptor, oestrogen receptor $\alpha, \mathrm{PGHS}-2$ ) within 
the endometrium at day 17 after oestrus between cyclic and pregnant non-lactating cows. Expression of oestrogen receptor $\alpha$ (that is, mRNA and protein) and oxytocin receptor mRNA was attenuated in pregnant cows. As endometrial PGHS-2 protein is high in pregnancy, there may be differential metabolism of $\mathrm{PGH}_{2}$ between pregnant and cyclic endometrium. Interferon $\tau$ stimulated basal secretion of $\mathrm{PGF}_{2 \alpha}$ from primary culture of endometrial epithelial cells but attenuated the phorbol ester induced increase in $\mathrm{PGF}_{2 \alpha}$ secretion. There appears to be cross-talk between bST and intrauterine regulatory systems of the cycle and pregnancy based on bST amplification of oestrogen receptor $\alpha$ and PGHS-2 proteins and attenuation in oxytocin mRNA. Responses to bST may differ markedly depending on whether cows are lactating or not. Programmed suppression of ovarian follicular development via insertion of a deslorelin implant tended to reduce early embryo losses but not late embryonic losses in lactating dairy cows. Perhaps exposure to oestradiol secreted by the ovarian follicle stimulates early embryonic losses.

\section{References}

Asselin $E$, Drolet $P$ and Fortier MA (1998) In vitro response to oxytocin and interferon-tau in bovine endometrial cells from caruncular and inter-caruncular areas Biology of Reproduction $59241-247$

Badinga L, Guzeloglu A and Thatcher WW (2002) Bovine somatotropin attenuates phorbol esterinduced prostaglandin $\mathrm{F}_{2 \alpha}$ production in bovine endometrial cells Journal of Dairy Science 85537 543

Bartolome JA, Kamimura S, Silvestre FT, Arteche ACM, Bilby TR, Archbald LF, Trigg T and Thatcher WW (2002) The use of a deslorelin implant during the late embryonic period to enhance embryo survival Journal of Animal Science 80 Supplement 1 Journal of Dairy Science 85 Supplement 1301 (Abstract)

Bezecny I, Bartova I and Skarda J (1992) Growth hormone treatment increases oestrogen receptor concentration in the guinea-pig uterus Journal of Endocrinology $1345-9$

Binelli M, Guzeloglu A, Badinga L, Arnold DR, Sirois J, Hansen TR and Thatcher WW (2000) Interferon-T modulates phorbol ester-induced production of prostaglandin and expression of cyclooxygenase-2 and phospholipase- $A_{2}$ from bovine endometrial cells Biology of Reproduction $63417-424$

Burke JM, De la Sota RL, Risco CA, Staples CR, Schmitt EJ-P and Thatcher WW (1996) Evaluation of timed insemination using a gonadotropin-releasing hormone agonist in lactating dairy cows Journal of Dairy Science 79 1385-1393

Charpigny G, Reinaud P, Tamby JP, Creminon C, Martal J, Maclouf J and Guillomot M (1997) Expression of cyclooxygenase -1 and -2 in ovine endometrium during the estrous cycle and early pregnancy Endocrinology $1382163-2171$

Danet-Desnoyers G, Wetzels C and Thatcher WW (1994) Natural and recombinant bovine interferon regulate basal and oxytocin-induced secretion of $\mathrm{PGF}_{2 \alpha}$ and $\mathrm{PGE}_{2}$ by endometrial epithelial and stromal celis Reproduction. Fertility and Development 6 193-202

De la Sota RL, Lucy MC, Staples CR and Thatcher WW (1993) Effects of recombinant bovine somatotropin (Sometribove) on ovarian function in lactating and non-lactating dairy cows Journal of Dairy Science $761002-1013$

Diaz T, Schmitt EJ-P, De la Sota RL, Thatcher M-J and Thatcher WW (1998) Human chorionic gonadotropin-induced alterations in ovarian follicular dynamics during the estrous cycle of heifers Journal of Animal Science 76 1929-1936

Guzeloglu A, Bilby TR, Kamimura S, Meikle A, Badinga L, Dinges AC, Hernandez $O$ and Thatcher WW (2002) Effects of pregnancy and bovine somatotrophin (bst) on endometrial oestrogen receptor- $\alpha$ (ER- $\alpha$ ), PGHS and $\mathrm{PGF}_{2 \alpha}$ secretion on day 17 after oestrus in non-lactating dairy cows Biology of Reproduction 66 Supplement 1314 (Abstract)

Humblot $\mathbf{P}$ (2002) Use of pregnancy specific proteins and progesterone assays to monitor pregnancy and determine the timing frequencies and sources of embryonic mortality in ruminants Theriogenology $\mathbf{5 6}$ 1417-1433

Ing NH, Spencer TE and Bazer FW (1996) Oestrogen enhances endometrial oestrogen receptor gene expression by a post-transcriptional mechanism in the ovariectomized ewe Biology of Reproduction 54 591-599

Jimenez-Krassel F, Binelli $\mathrm{M}$, Tucker $\mathrm{HA}$ and Ireland J) (1999) Effect of long-term infusion with recombinant growth hormone-releasing factor and recombinant bovine somatotropin on development and function of dominant follicles and corpora lutea in Holsein cows Journal of Dairy Science 82 19171926

Kelly RW, King AE and Critchley HOD (2001) Cytokine control in human endometrium Reproduction 121 $3-19$ 
Kim S, Choi Y, Bazer F and Spenser T (2002) Effects of the estrous cycle, pregnancy and interferon $\tau$ on cyclooxygenase 2 (COX-2) expression in ovine endometrium Biology of Reproduction 66 Supplement 1267 (Abstract)

Klotz DM, Hewitt SC, Ciana P, Raviscioni M, Lindzey JK, Foley J, Maggi A, DiAugustine RP and Korach KS (2002) Requirement of estrogen receptor- $\alpha$ in insulinlike growth factor-1 (IGF-1)-induced uterine responses and in vivo evidence for 1 GF-1/oestrogen receptor cross-talk Journal of Biological Chemistry 2778531 8537

Kombe A, Sirois J and Goff AK (2002) The effect of progesterone and estradiol on the sensitivity of endometrial epithelial cells to oxytocin Biology of Reproduction 66 Supplement 1322 (Abstract)

Liu J, Antaya M, Goff AK, Boerboom D, Silversides DW, Lussier JG and Sirois J (2001) Molecular characterization of bovine prostaglandin $\mathrm{G} / \mathrm{H}$ Synthase-2 and regulation on uterine stromal cells Biology of Reproduction 64 983-991

Lucy MC (2000) Regulation of ovarian follicular growth by somatotropin and insulin-like growth factors in cattle Journal of Dairy Science 83 1635-1647

Lucy MC (2001) Reproductive loss in high-producing dairy cattle: where will it end? Journal of Dairy Science 84 1277-1293

Mann GE, Lamming GE, Robinson RS and Wathes DC (1999) The regulation of interferon- production and uterine hormone receptors during early pregnancy Journal of Reproduction and Fertility Supplement $\mathbf{5 4}$ $317-328$

Mattos R, Orlandi C, Williams J, Staples CR, Trigg T and Thatcher WW (2001) Effect of an implant containing the $\mathrm{GnRH}$ agonist deslorelin on secretion of $\mathrm{LH}$, ovarian activity and milk yield of postpartum dairy cows Theriogenology 56 371-386

Morales IS, Zarco L, Hernández-Cerón and Rodriguez G (2001) Effect of short-term treatment with bovine somatotropin at oestrus on conception rate and luteal function of repeat-breeding dairy cows Theriogenology 55 1831-1841

Moreira F, Risco CA, Pires MFA, Ambrose JD, Drost $M$ and Thatcher WW (2000) Use of bovine somatotropin in lactating dairy cows receiving timed artificial insemination Journal of Dairy Science $\mathbf{8 3}$ $1237-1247$

Moreira F, Orlandi C, Risco CA, Mattos R, Lopes F and Thatcher WW (2001) Effects of presynchronization and bovine somatotropin on pregnancy rates to a timed artificial insemination protocol in lactating dairy cows Journal of Dairy Science 84 1646-1659

Moreira F, Paula-Lopes FF, Hansen PJ, Badinga L and Thatcher WW (2002) Effects of growth hormone and insulin-like growth factor I on development of in vitro derived bovine embryos Theriogenology 57 895-907

Pershing RA, Thatcher WW and Badinga L (2001) Effects of bovine somatotropin on oviductal and uter- ine genes encoding components of the IGF system in lactating dairy cows Biology of Reproduction 62 Supplement 1266 (Abstract)

Pursley JR, Kosorok MR and Wiltbank MC (1997) Reproductive management of lactating dairy cows using synchronization of ovulation Journal of Dairy Science $80301-306$

Pushpakumara PGA, Robinson RS, Demmers KJ, Mann GE, Sinclair KD, Webb $R$ and Wathes DC (2002) Expression of the insulin-like growth factor (IGF) system in the bovine oviduct at oestrus and during early pregnancy Reproduction 123 859-868

Robinson RS, Mann GE, Lamming GE and Wathes DC (2001) Expression of oxytocin, oestrogen and proges. terone receptors in uterine biopsy samples throughout the oestrous cycle and early pregnancy in cows Reproduction 122 965-979

Santos JEP, Thatcher WW, Pool L and Overton MW (2001) Effect of human chorionic gonadotropin on luteal function and reproductive performance of high-producing lactating Holstein dairy cows Journal of Animal Science $792881-2894$

Santos JEP, Juchem SO, Cerri RLA, Dei C, Thatcher WW and Bilby C (2002a) Effect of bST and reproductive management on reproductive and lactational performance of Holstein cows Journal of Animal Science 80 Supplement 1//ournal of Dairy Science 85 Supplement 1265 (Abstract)

Santos JEP, Bartolome J, Cerri RLA, Juchem SO, Trigg TE and Thatcher WW (2002b) Effect of a deslorelin implant in a timed $\mathrm{Al}$ protocol on follicle development, luteal activity and reproductive performance of dairy cows Journal of Animal Science 80 Supplement 1 Journal of Dairy Science 85 Supplement 1263 (Abstract)

Thatcher WW, Driancourt MA, Terqui M and Badinga L (1991) Dynamics of ovarian follicular development in cattle following hysterectomy and during early pregnancy Domestic Animal Endocrinology 8 223234

Thatcher WW, Guzeloglu A, Mattos R, Binelli M, Hansen TR and Pru JK (2001) Uterine-conceptus interactions and reproductive failure in cattle Theriogenology 56 1435-1450

Wathes DC, Reynolds TS, Robinson RS and Stevenson KR (1998) Role of the insulin-like growth factor system in uterine function and placental develop. ment in ruminants fournal of Dairy Science $\mathbf{8 1}$ $1778-1789$

Xiao CW, Murphy BD, Sirois J and Goff AK (1999) Down-regulation of oxytocin-induced cyclooxygenase-2 and prostaglandin $F$ synthase expression by interferon- $\tau$ in bovine endometrial cells Biology of Reproduction $\mathbf{6 0}$ 656-663

Yang $\mathrm{CH}$, Murti A, Pfeffer SR, Kim JG, Conner DB and Pfeffer LM (2001) Interferon $\alpha / \beta$ promotes cell survival by activating nuclear factor $\kappa B$ through phosphatidylinositol 3-kinase and Akt Journal of Biological Chemistry 276 13 756-13 761 